\title{
Analisis Manfaat Teh Kurkumin Kunyit Dan Pemakaian K3 Pada Petani Wanita Untuk Pencegahan Kanker Multiple Myeloma Di Berastagi Kab. Karo
} Tahun 2019

\author{
Ester Simanullang1, Ninsah Mandala Putri2, Mediana Sembiring3, Lidya Sinuhaji 4 \\ 1,2, Program Studi Sarjana Terapan STIKes Mitra Husada Medan \\ 3,4 Program Studi Diploma Tiga STIKes Mitra Husada Medan \\ Coresponden author: Telepon : 085270070664, E-mail:lidyasinuhaji23@gmail.com
}

Abstrak
Latar belakang: Di Indonesia, sekitar $80 \%$ penderita penyakit kanker ditemukan pada stadium
lanjut sehingga pengobatan menjadi lebih sulit, mahal dan hasil pengobatan tidak memuaskan,
bahkan cenderung mempercepat kematian (Dalimartha, 2004). Penggunaan pestisida merupakan
permasalahan yang perlu diperhatikan terutama dalam aspek keselamatan dan kesehatan kerja.
Penelitian ini bertujuan untuk menganalisis pemanfaatan teh kurkumin kunyit dan pemakaian alat
pelindung diri untuk kesehatan keselamatan kerja terhadap pencegahan kanker multiple myeloma
untuk kesehatan pada petani wanita di Kabupaten Karo.
Metode: Jenis penelitian ini adalah explanatory research dengan pendekatan cross sectional. Sampel
diambil dengan teknik purposive sampling dari seluruh populasi penyemprot pestisida di Kecamatan
Berastagi. Data dikumpulkan melalui observasi dan wawancara langsung. Variabel yang diteliti
adalah pemanfaatan Teh kurkumin kunyit dan Kesehatan Kesematan Kerja (K3) pada petani wanita.
Hasil yang diperoleh dianalisa dengan menggunakan uji Chi square.
Hasil: Hasil penelitian menunjukkan bahwa terdapat hubungan yang signifikan antara jenis lama
penyemprotan dengan tidak menggunakan kesehatan keselamatan kerja (p value=0,021), lama kerja
(p value=0,002), dan frekuensi lama penyemprotan (jam/hari) dengan p value=0,018 dengan keluhan
kesehatan yang dirasakan petani. Frekuensi penyemprotan juga tidak memiliki hubungan dengan
keluhan kesehatan.
Simpulan: Petani penyemprot pestisida di Kecamatan Berastagi berisiko mengalami keracunan
pestisida melalui kontak langsung akibat tidak menggunakan pelindung. Pengobatan tradisional
merupakan bagian dari sistem budaya masyarakat yang potensi manfaatnya sangat besar dalam
pembangunan kesehatan masyarakat. Pemanfaatan kurkumin kunyit untuk pengobatan sendiri (self
care) cenderung meningkat. Sebagai langkah awal yang sangat membantu untuk mengetahui suatu
tumbuhan berkhasiat obat adalah dari pengetahuan masyarakat tradisional secara turun temurun.
Kata Kunci: Keselamatan Kesehatan Kerja,Kurkumin Kunyit,Pencegahan Kanker Multiple
Myeloma




\begin{abstract}
Background: In Indonesia, about $80 \%$ of cancer sufferers are found at an advanced stage so that treatment becomes more difficult, expensive and the results of treatment are unsatisfactory, and even tends to accelerate death (Dalimartha, 2004). The use of pesticides is a problem that needs attention, especially in terms of occupational safety and health. This study aims to analyze the use of turmeric curcumin tea and the use of personal protective equipment for occupational health safety against the prevention of multiple myeloma cancer for health in female farmers in Karo District.

Method: This type of research is explanatory research with cross sectional approach. Samples were taken by purposive sampling technique from the entire population of pesticide sprayers in Berastagi District. Data collected through observation and direct interviews. The variables studied were the use of turmeric curcumin tea and Occupational Health (K3) in female farmers. The results obtained were analyzed using the Chi square test.

Results: The results showed that there was a significant relationship between types of spraying time without using occupational health safety ( $p$ value $=0.021)$, working time $(p$ value $=0.002)$, and frequency of spraying time (hours / day) with p value $=0.018$ with health complaints felt by farmers. The frequency of spraying also has no relationship with health complaints. Pesticide spraying farmers in Berastagi District are at risk of experiencing pesticide poisoning through direct contact due to not using protection. Traditional medicine is part of the cultural system of the community which has huge potential benefits in the development of public health. The use of turmeric curcumin for self-medication (self care) tends to increase. As a first step that is very helpful to know a medicinal plant is from traditional community knowledge for generations.
\end{abstract}

Keywords: Curcumin Turmeric, Occupational Health Safety, Prevention of Multiple Myeloma Cancer

\title{
Pendahuluan
}

Berdasarkan daftar badan kesehatan dunia (WHO) penyakit kanker masih dalam urutan teratas dari kelompok penyakit yang paling mematikan di dunia, setiap tahun jumlah penderita kanker di dunia bertambah 6,25 juta orang. Dalam 10 tahun mendatang diperkirakan 9 juta orang akan meninggal setiap tahun akibat kanker. Dua pertiga dari penderita kanker di dunia akan berada di negara-negara yang sedang berkembang
(Anonim, 2006). Di dunia penyakit ini menempati urutan kedua sebagai penyebab kematian, sedangkan di Indonesia menempati urutan keenam (Dalimartha, 2004). Insidensi kanker di Indonesia diperkirakan 100 orang per 10.000 penduduk setiap tahun (Anonim, 2006). Di Indonesia, sekitar $80 \%$ penderita penyakit kanker ditemukan pada stadium lanjut sehingga pengobatan menjadi lebih sulit, mahal dan hasil pengobatan tidak 
Dinamika Kesehatan Jurnal Kebidanan dan Keperawatan Vol 10 No. 2 Desember 2019 ( ISSN: 2086-3454 EISSN: 2549-4058)

url: http://ojs.dinamikakesehatan.unism.ac.id DOI : https://doi.org/10.33859/dksm.v10i2

Analisis Manfaat Teh Kurkumin Kunyit Dan Pemakaian K3 Pada Petani Wanita Untuk Pencegahan Kanker Multiple Myeloma Di Berastagi Kab. Karo Tahun 2019

memuaskan, bahkan cenderung mempercepat

kematian (Dalimartha, 2004).

Penelitian ilmiah yang berhasil

mengungkapkan khasiat, manfaat

pengobatan, dan terapi kanker mendorong

munculnya paradigma baru dalam dunia

pengobatan modern, yaitu back to nature atau

kembali ke alam (Mangan, 2003).

Keanekaragaman hayati Indonesia sangat

berpotensi dalam penentuan senyawa baru

yang berkhasiat sebagai antikanker, salah

satunya adalah tanaman Curcumin, demikian

nama senyawa kimia itu, bisa ditemukan di

dalam kunyit yang lama diyakini sangat

bermanfaat untuk kesehatan manusia.

Sejumlah penelitian menunjukkan bahwa

kunyit dapat mematikan sel kanker dan

kemungkinan bisa juga mengobati stroke

serta demensia. Kini sebuah rumah sakit di

Leicester, Inggris tengah mencoba untuk

memberikan curcumin kepada pasien kanker

selain kemoterapi dan pengobatan lainnya. Di

Inggris, setiap tahun sekitar 4000 orang

didiagnosa menderita penyakit kanker. Jika

penyakit itu sudah menyebar ke seluruh tubuh, pasien biasanya menjalani terapi

dengan kombinasi tiga obat kemoterapi, namun sekitar separuh pasien tidak merespon obat tersebut. Sebanyak 40 orang pasien dua rumah sakit di Leicester mengikuti uji coba ini. Dokter akan membandingan efek pemberian curcumin tujuh hari sebelum kemoterapi dilakukan.

Profesor William Steward, pemimpin uji coba ini mengatakan saat diuji coba terhadap hewan kombinasi kemoterapi dan curcumin terbukti 100 kali lebih menghasilkan efek bagus ketimbang salah satu upaya pengobatan saja. Prospek curcumin meningkatkan sensitivitas sel kanker terhadap kemoterapi sangat menggembirakan, sebab itu berarti dosis obat yang diberikan akan lebih rendah sehingga pasien akan menderita efek samping yang minim dan bisa mendapatkan pengobatan lebih lama.

Penelitian ini, kata Steward, masih dalam tahap awal. Namun investigasi ini diharapkan pada akhirnya bisa menyediakan jenis obat baru di masa depan. Dengan 
Dinamika Kesehatan Jurnal Kebidanan dan Keperawatan Vol 10 No. 2 Desember 2019 ( ISSN: 2086-3454 EISSN: 2549-4058)

url: http://ojs.dinamikakesehatan.unism.ac.id DOI : https://doi.org/10.33859/dksm.v10i2

Analisis Manfaat Teh Kurkumin Kunyit Dan Pemakaian K3 Pada Petani Wanita Untuk Pencegahan Kanker Multiple Myeloma Di Berastagi Kab. Karo Tahun 2019

melakukan penelitian ini, kami akan

Menurut Fadhilah, Suryanto, dan Ulfah

mengetahui tentang keuntungan potensial

(2013) setiap hari rata-rata 6.000 orang

mengkonsumsi curcumin dalam jumlah

besar, di samping efek samping yang

mungkin dialami para penderita kanker dari

Pusat Penelitian Kanker Inggris.

Terapi pengobatan kanker yang utama seperti pembedahan dan radiasi hanya dilakukan pada kanker lokal stadium awal. Pengobatan ini gagal digunakan untuk kanker yang telah berkembang pada stadium lanjut dan sudah mengalami metastatis (Sukardja, 2000). Karena itulah pilihan pengobatan baru yang aman, efektif dan selektif pada penyakit ini sangat penting (Handayani et al., 2001).Penelitian ilmiah yang berhasil mengungkapkan khasiat, manfaat pengobatan, dan terapi kanker mendorong munculnya paradigma baru dalam dunia pengobatan modern, yaitu back to nature atau kembali ke alam (Mangan, 2003). Keanekaragaman hayati Indonesia sangat berpotensi dalam penentuan senyawa baru yang berkhasiat sebagai antikanker, salah satunya adalah tanaman. 
Dinamika Kesehatan Jurnal Kebidanan dan Keperawatan Vol 10 No. 2 Desember 2019 ( ISSN: 2086-3454 EISSN: 2549-4058)

url: http://ojs.dinamikakesehatan.unism.ac.id DOI : https://doi.org/10.33859/dksm.v10i2

Analisis Manfaat Teh Kurkumin Kunyit Dan Pemakaian K3 Pada Petani Wanita Untuk Pencegahan Kanker Multiple Myeloma Di Berastagi Kab. Karo Tahun 2019

No. 1 tahun 1970 tentang Keselamatan Kerja

bab IX pasal 13 dimana disebutkan bahwa barangsiapa yang memasuki suatu tempat kerja maka diwajibkan mentaati semua petunjuk keselamatan kerja dan menggunakan alat pelindung diri yang diwajibkan.

Faktor yang mempengaruhi persepsi petani dalam menerapkan K3 salah satunya adalah karakteristik petani. Karakteristik petani merupakan suatu cermin status sosial individu petani yang mempengaruhi dalam pengambilan keputusan dalam lingkungannya (Awal, Sativa, and Suratno 2014). Karakteristik petani dapat dipengaruhi oleh demografis, sosial, ekonomi hingga budaya. Dalam penelitian ini, karakteritik petani dibatasi pada umur, tingkat pendidikan, pelatihan, pendapatan, lama usahatani, status kepemilikan lahan dan luas lahan. Sedangkan persepsi adalah suatu proses pemahaman kompleks terhadap objek yang dilihat dalam lingkungannya (Prayitno, Saam, and Nurhidayah 2014). Menurut Priambodo and Prabawani (2016) dengan teori Technology Acceptance Model (TAM), menyatakan bahwa persepsi dibagi menjadi dua yaitu persepsi kemudahan (Perceived easy to use) dan persepsi kebermanfaatan (Perceived Usefulness) yang mempengaruhi sikap dan niat untuk adopsi. Dimana semakin besar persepsi terhadap risiko akan mengurangi persepsi terhadap keuntungan untuk adopsi sebuah teknologi (Gefen 2002). Menurut Hillson and Murray-Webster (2005) menyatakan risiko merupakan suatu penilaian terhadap perubahan yang

dampaknya berbeda dari yang diperkirakan. Berdasarkan permasalahan di atas, maka penelitian ini dilakukan untuk menganalisis hubungan antara karakteristik petani terhadap persepsi penerapan $\mathrm{K} 3$ dalam kegiatan usahatani di Berastagi Kabupaten Karo.

\section{Metode}

Jenis penelitian yang dilakukan adalah explanatory research yang berift deskriptif dengan rancangan penelitian menggunakan endekatan cross sectional oleh karena pengamatan subjek hanya dilakukan sekali saja. Metode pengumpulan data dalam penelitian ini dilakukan melalui 2 cara yaitu: 
Dinamika Kesehatan Jurnal Kebidanan dan Keperawatan Vol 10 No. 2 Desember 2019 ( ISSN: 2086-3454 EISSN: 2549-4058) url: http://ojs.dinamikakesehatan.unism.ac.id DOI : https://doi.org/10.33859/dksm.v10i2

Analisis Manfaat Teh Kurkumin Kunyit Dan Pemakaian K3 Pada Petani Wanita Untuk Pencegahan Kanker Multiple Myeloma Di Berastagi Kab. Karo Tahun 2019

a. Observasi dimana keseluruhan proses kerja petani dalam akan diamati langsung mulai dari proses pencampuran pestisida hingga pasca penyemprotan pestisida dan penggunaan kesehatan keselamatan kerja dan pemanfaatan kurkumin kunyit.

b. Wawancara langsung untuk mengetahui hal-hal yang berkaitan dalam penggunaan pestisida dan upaya untuk mengatasi kesehatan yang dapat mendukung hasil observasi guna memperdalam hasil penelitian

Unit analisis dalam penelitian ini meliputi dengan keluhan kesehatan yang dirasakan oleh petani yang berhubungan dengan kesehatan keselamatan kerja (K3).Teknik analisa data dilakukan dengan menggunakan uji chi-square untuk melihat hubungan antara pemanfaatan teh kurkumin kunyit dan pemakaian kesehatan keselamatan kerja (K3) dengan keluhan kesehatan yang dialami petani di Kecamatan Berastagi.

\section{Hasil Dan Pembahasan}

\section{Umur}

Table 1. Distribusi Responden Menurut Kelompok Umur

\begin{tabular}{|l|c|c|}
\hline \multicolumn{1}{|c|}{ Umur } & Frekuensi & $\begin{array}{l}\text { Prosentase } \\
(\%)\end{array}$ \\
\hline & & \\
\hline$<30$ tahun & 10 & 8,6 \\
\hline $30-39$ tahun & 39 & 33,9 \\
\hline $40-49$ tahun & 45 & 39,1 \\
\hline$>50$ tahun & 21 & 18,2 \\
\hline Jumlah & 115 & 100 \\
\hline
\end{tabular}

Berdasarkan Tabel 1 di atas menunjukkan mayoritas responden usia 40-49 tahun sebanyak 45 orang $(39,1,3 \%)$ dan responden paling sedikit <30 tahun yaitu sebanyak 10 orang $(8,6 \%)$.

\section{Pendidikan}

Table 2. Distribusi Responden Menurut Kelompok Umur

\begin{tabular}{|l|c|c|}
\hline Pendidikan & Frekuensi & $\begin{array}{c}\text { Prosentase } \\
(\mathbf{\%})\end{array}$ \\
\hline Tidak Tamat SD & 22 & 19,1 \\
\hline SD & 12 & 33,9 \\
\hline SMP & 31 & 10,4 \\
\hline SMA & 40 & 34,7 \\
\hline Sarjana & 10 & 8,6 \\
\hline Jumlah & 115 & 100 \\
\hline
\end{tabular}

Berdasarkan Tabel 2 di atas menunjukkan mayoritas responden pendidikn tamat SMA sebanyak 40 orang $(34,7 \%)$ dan responden paling sedikit pendidikan sarjana yaitu sebanyak 10 orang $(8,6 \%)$. 
Dinamika Kesehatan Jurnal Kebidanan dan Keperawatan Vol 10 No. 2 Desember 2019 ( ISSN: 2086-3454 EISSN: 2549-4058) url: http://ojs.dinamikakesehatan.unism.ac.id DOI : https://doi.org/10.33859/dksm.v10i2

Analisis Manfaat Teh Kurkumin Kunyit Dan Pemakaian K3 Pada Petani Wanita Untuk Pencegahan Kanker Multiple Myeloma Di Berastagi Kab. Karo Tahun 2019

3. Lama menjadi petani

Tabel 3. Distribusi Responden Lama menjadi petani

\begin{tabular}{|l|c|c|}
\hline $\begin{array}{c}\text { Lama } \\
\text { Menjadi } \\
\text { Petani }\end{array}$ & Frekuensi & $\begin{array}{c}\text { Prosent } \\
\text { ase (\%) }\end{array}$ \\
\hline $1-20$ & 34 & 29,5 \\
\hline $21-40$ & 69 & 60 \\
\hline$>40$ tahun & 12 & 10,4 \\
\hline Jumlah & 115 & 100 \\
\hline
\end{tabular}

Berdasarkan Tabel 3 di atas menunjukkan mayoritas responden lama menjadi petani sekitar 21-40 tahun sebanyak 69 orang $(60 \%)$ dan responden paling sedikit lama menjadi petani $>40$ tahun yaitu sebanyak 12 orang $(10,4 \%)$

\section{Keluhan Kesehatan}

Tabel 4. Distribusi Responden Keluhan Kesehatan

\begin{tabular}{|c|c|c|c|c|c|c|c|}
\hline \multirow[t]{2}{*}{ No } & \multirow{2}{*}{$\begin{array}{l}\text { Keluhan } \\
\text { Kesehatan }\end{array}$} & \multicolumn{2}{|c|}{ Ya } & \multicolumn{2}{|c|}{ Tidak } & \multirow[t]{2}{*}{ Jlh } & \multirow[t]{2}{*}{$\%$} \\
\hline & & $\mathbf{N}$ & $\%$ & $\mathbf{N}$ & $\%$ & & \\
\hline 1 & Batuk & $\begin{array}{l}1 \\
1 \\
2\end{array}$ & 97,3 & 3 & 2,7 & 115 & 100 \\
\hline 2 & $\begin{array}{l}\text { Batuk } \\
\text { Sepanjang } \\
\text { Hari (pagi, } \\
\text { siang, } \\
\text { malam) }\end{array}$ & $\begin{array}{l}9 \\
8\end{array}$ & 85,2 & 17 & 14,8 & 115 & 100 \\
\hline 3 & $\begin{array}{l}\text { Batuk } 3 \\
\text { bulan setiap } \\
\text { tahunnya }\end{array}$ & $\begin{array}{l}5 \\
9\end{array}$ & 51,3 & 56 & 48,7 & 115 & 100 \\
\hline 4 & $\begin{array}{l}\text { Mual dan } \\
\text { muntah }\end{array}$ & $\begin{array}{l}7 \\
9 \\
\end{array}$ & 68,7 & 36 & 31,3 & 115 & 100 \\
\hline 5 & $\begin{array}{l}\text { Keluhan } \\
\text { batuk } \\
\text { berdahak } \\
\text { (pagi, siang, } \\
\text { malam) }\end{array}$ & $\begin{array}{l}7 \\
0\end{array}$ & 60,9 & 45 & 39,1 & 115 & 100 \\
\hline 6 & Sesak Nafas & $\begin{array}{l}4 \\
8 \\
\end{array}$ & 41,8 & 67 & 58,2 & 115 & 100 \\
\hline 7 & $\begin{array}{l}\text { Terbangun } \\
\text { malam hari } \\
\text { karena sesak } \\
\text { nafas }\end{array}$ & $\begin{array}{l}4 \\
8\end{array}$ & 41,8 & 67 & 58,2 & 115 & 100 \\
\hline 8 & $\begin{array}{l}\text { Sesak nafas } \\
\text { bila bekerja } \\
\text { berat }\end{array}$ & $\begin{array}{l}8 \\
8\end{array}$ & 75,6 & 27 & 23,4 & 115 & 100 \\
\hline 9 & $\begin{array}{l}\text { Nafas } \\
\text { berbunyi }\end{array}$ & $\begin{array}{l}3 \\
4 \\
\end{array}$ & 29,6 & 81 & 70,4 & 115 & 100 \\
\hline 10 & $\begin{array}{l}\text { Sering } \\
\text { mengalami } \\
\text { alergi } \\
\end{array}$ & $\begin{array}{l}6 \\
9\end{array}$ & 60 & 46 & 40 & 115 & 100 \\
\hline
\end{tabular}

\begin{tabular}{|c|c|c|c|c|c|c|c|}
\hline & $\begin{array}{l}\text { (pilek, } \\
\text { bersin \& } \\
\text { hidung } \\
\text { tersumbat) }\end{array}$ & & & & & & \\
\hline 11 & $\begin{array}{l}\text { Merasakan } \\
\text { sakit di dada }\end{array}$ & $\begin{array}{l}1 \\
1 \\
2\end{array}$ & 97,3 & 3 & 2,7 & 115 & 100 \\
\hline 12 & $\begin{array}{l}\text { Sering } \\
\text { mengalami } \\
\text { demam }\end{array}$ & $\begin{array}{l}9 \\
8\end{array}$ & 85,2 & 17 & 14,8 & 115 & 100 \\
\hline
\end{tabular}

Dari tabel diatas, dapat dilihat keluhan meliputi batuk, berdahak, sesak nafas, nafas berbunyi, dan alergi. Dari hal tersebut terbanyak mengalami sesak di dada yaitu sebanyak 112 orang $(97,3 \%)$ dan keluhan yang paling sedikit nafas berbunyi yaitu 34 orang $(29,6 \%)$. pada umumnya protein yang dihasilkan oleh sek myeloma dapat membehayakn ginjal. Dalam jangka panjang, kondisi ini bias mengakibatkan keruskaan ginjal dan gagal gija; yang diawali dengan tubuh lemah, nafas memendek, sering demam

\section{Resiko Lama Penyemprotan dengan keluhan Petani}

Lama penyemprotan yang dilakukan di tiap lahan petani rata-rata 3 jam $(43,3 \%)$. Namun masih ada juga yang melakukan penyemprotan selama 6 jam per hari. Sedangkan frekuensi penyemprotan yang dilakukan 27 orang $(23,4 \%)$ terbanyak melakukan sebanyak 3 kali penyemprotan, 38 orang $(33 \%)$ frekuensi penyemprotan 
Dinamika Kesehatan Jurnal Kebidanan dan Keperawatan Vol 10 No. 2 Desember 2019 ( ISSN: 2086-3454 EISSN: 2549-4058) url: http://ojs.dinamikakesehatan.unism.ac.id DOI : https://doi.org/10.33859/dksm.v10i2

Analisis Manfaat Teh Kurkumin Kunyit Dan Pemakaian K3 Pada Petani Wanita Untuk Pencegahan Kanker Multiple Myeloma Di Berastagi Kab. Karo Tahun 2019

sebanyak 3 kali dan 2 orang 28 dan 26 orang

frekuensi penyemprotansebanyak 7 kali sebanyak 34 orang . Hasil uji chi square menunjukkan bahwa frekuensi penyemprotan berdasarkan lama penyemprotan (jam/hari) memiliki hubungan dengan keluhan kesehatan dimana $\mathrm{p}$ value $=0,018$. Namun frekuensi penyemprotan berdasarkan berapa kali melakukan penyemprotan tidak memiliki hubungan yang significant dengan keluhan yang dirasakan petani $(\mathrm{p}$ value $=0,406)$

Tabel 5. Tabulasi Silang Frekuensi Lama Penyemprotan dengan Keluhan Petani Penyemprot di Kecamatan Berastagi

\begin{tabular}{|c|c|c|c|c|c|}
\hline $\begin{array}{c}\mathbf{N} \\
\mathbf{0}\end{array}$ & $\begin{array}{c}\text { Frek } \\
\text { uens } \\
\text { i } \\
\text { Peny } \\
\text { emp } \\
\text { rota } \\
\text { n }\end{array}$ & $\begin{array}{l}\text { Keluhan } \\
\text { Petani } \\
\text { Penyemprot } \\
\quad \text { Ada }\end{array}$ & $\begin{array}{c}\text { Tidak } \\
\text { Ada }\end{array}$ & $\begin{array}{c}\text { Tot } \\
\text { al }\end{array}$ & $\mathbf{P}$ \\
\hline 1 & $2 \mathrm{jam}$ & 10 & 2 & 12 & 0,0 \\
\hline 2 & 3 jam & 13 & 6 & 19 & \\
\hline 3 & 4 jam & 44 & 4 & 48 & \\
\hline 4 & $6 \mathrm{jam}$ & 27 & 9 & 36 & \\
\hline $\begin{array}{l}\mathrm{T} \\
\text { ot } \\
\text { al }\end{array}$ & & 94 & 21 & 115 & \\
\hline
\end{tabular}

Tabel 6. Tabulasi Silang Frekuensi Penyemprotan dengan Keluhan Petani Penyemprot di Kecamatan Berastagi

\begin{tabular}{|c|c|c|c|c|c|}
\hline $\begin{array}{c}\mathbf{N} \\
\mathbf{0}\end{array}$ & $\begin{array}{c}\text { Freku } \\
\text { ensi } \\
\text { Penye } \\
\text { mprot } \\
\text { an }\end{array}$ & $\begin{array}{l}\text { Keluhan } \\
\text { Petani } \\
\text { Penyempr } \\
\text { ot } \\
\text { Ada }\end{array}$ & $\begin{array}{c}\text { Tidak } \\
\text { Ada }\end{array}$ & Total & $\begin{array}{c}\mathbf{P}(\mathbf{C I} \\
=\mathbf{0 , 0} \\
5)\end{array}$ \\
\hline 1 & $1 \mathrm{kali}$ & 3 & 7 & 7 & 0,406 \\
\hline 2 & 2 kali & 28 & 5 & 13 & \\
\hline 3 & 3 kali & 36 & 2 & 8 & \\
\hline 4 & 7 kali & 34 & 0 & 2 & \\
\hline $\begin{array}{l}\mathrm{T} \\
\text { ot } \\
\text { al }\end{array}$ & & 89 & 14 & 115 & \\
\hline
\end{tabular}

Pekerja yang bekerja dalam jangka waktu yang cukup lama dengan pestisida akan mengalami keracunan yang menahun, artinya makin lama bekerja maka akan semakin bertambah jumlah pestisida yang terabsorbsi dan mengakibatkan menurunnya aktivitas cholinesterase. Menurut Permenaker No. Per03/Men1986 pasal 2 ayat 2a dinyatakan bahwa untuk menjaga efek yang tidak diinginkan maka dianjurkan supaya tidak melebihi 4 jam sehari dalam seminggu berturut-turut bila menggunakan pestisida. Sementara WHO menerapkan lama penyemprotan terpajan pestisida saat bekerja selama 5-6 jam per hari dan setiap minggu harus dilakukan pengujian kesehatan termasuk kadar cholinesterase darah. 
Dinamika Kesehatan Jurnal Kebidanan dan Keperawatan Vol 10 No. 2 Desember 2019 ( ISSN: 2086-3454 EISSN: 2549-4058)

url: http://ojs.dinamikakesehatan.unism.ac.id DOI : https://doi.org/10.33859/dksm.v10i2

Analisis Manfaat Teh Kurkumin Kunyit Dan Pemakaian K3 Pada Petani Wanita Untuk Pencegahan Kanker Multiple Myeloma Di Berastagi Kab. Karo Tahun 2019

3. Hasil wawancara dengan petani mengenai upaya pencegahan

\subsection{Pendidikan dan Pelatihan}

Tabel 7 Distribusi Responden Berdasarkan Pendidikan dan pelatihan mengenai upaya pencegahan

\begin{tabular}{|c|c|c|c|c|c|c|c|}
\hline \multirow{2}{*}{$\begin{array}{l}\mathrm{N} \\
\mathrm{O}\end{array}$} & \multirow{2}{*}{$\begin{array}{c}\text { Pendidikan dan } \\
\text { pelatihan }\end{array}$} & \multicolumn{2}{|c|}{$\mathrm{Ya}$} & \multicolumn{2}{|c|}{ Tidak } & \multirow{2}{*}{$\begin{array}{l}\mathrm{Jl} \\
\mathrm{h}\end{array}$} & \multirow[t]{2}{*}{$\%$} \\
\hline & & $\mathrm{N}$ & $\%$ & $\mathrm{~N}$ & $\%$ & & \\
\hline 1 & $\begin{array}{l}\text { Mengikuti } \\
\text { pendidikan dan } \\
\text { pelatihan } \\
\text { mengenai } \\
\text { masalah } \\
\text { keselamatan } \\
\text { dan kesehatan } \\
\text { kerja (K3) }\end{array}$ & 0 & 0 & 115 & 100 & $\begin{array}{l}1 \\
1 \\
5\end{array}$ & 100 \\
\hline 2 & $\begin{array}{l}\text { Mengetahui } \\
\text { bahwa pestisida } \\
\text { membahayakan } \\
\text { kesehatan }\end{array}$ & $\begin{array}{l}1 \\
1 \\
5\end{array}$ & $\begin{array}{l}1 \\
0 \\
0\end{array}$ & 0 & 0 & $\begin{array}{l}1 \\
1 \\
5\end{array}$ & 100 \\
\hline 3 & $\begin{array}{l}\text { Tahu dengan } \\
\text { menggunkan } \\
\text { Alat Pelindung } \\
\text { diri seperti } \\
\text { masker dan } \\
\text { meminum the } \\
\text { kunyit dapat } \\
\text { mencegah } \\
\text { gangguan } \\
\text { kesehatan }\end{array}$ & $\begin{array}{l}1 \\
1 \\
3\end{array}$ & $\begin{array}{l}9 \\
8, \\
2\end{array}$ & 2 & 1,8 & $\begin{array}{l}1 \\
1 \\
5\end{array}$ & 100 \\
\hline 4 & $\begin{array}{l}\text { Pernah } \\
\text { mengikuti } \\
\text { penyuluhan } \\
\text { tentang } \\
\text { kegunaan alat } \\
\text { pelindung diri } \\
\text { (APD) dan } \\
\text { meminum the } \\
\text { kurkumin } \\
\text { kunyit }\end{array}$ & 0 & 0 & 115 & 100 & $\begin{array}{l}1 \\
1 \\
5\end{array}$ & 100 \\
\hline
\end{tabular}

Dari 115 (100\%) yang ditanyakan secara keseluruhan masyarakat tidak pernah mengikuti pendidikan dan pelatihan mengenai masalah keselamatan dan kesehatan kerja (K3). Dari 115 (100\%) responden yang mengetahui bahwa pestisida membahayakan kesehatan mereka memperoleh informasi dari dokter, majalah/koran dan teman kerja. Dari 115 responden, terdapat $2(1,8 \%)$ responden yang menggunakan alat pelindung diri seperti masker kesehatan dan meminum ramuan kesehatan seperti kurkumin kunyit untuk mencegah gangguan mereka tau informasi dari majalah/Koran, teman kerja. Dari 115 responden $(100 \%)$ yang ditanyakan secara keseluruhan menyatakan tidak pernah mengikuti penyuluhan tentang keselamatan dan kesehatan kerja (K3) untuk mencegah gangguan kesehatan pada petani.

Tabel 8 Upaya Pencegahan dengan Alat Pelindung Diri (APD) dan meminum minuman teh kurkumin kunyit

\begin{tabular}{|c|c|c|c|c|c|c|c|}
\hline \multirow{2}{*}{$\begin{array}{l}\mathrm{N} \\
\mathrm{O}\end{array}$} & \multirow{2}{*}{$\begin{array}{l}\text { Pendidikan } \\
\text { dan pelatihan }\end{array}$} & \multicolumn{2}{|c|}{$\mathrm{Ya}$} & \multirow{2}{*}{$\begin{array}{c}\text { Tida } \\
\mathrm{k}\end{array}$} & \multicolumn{2}{|c|}{ Jlh } & \multirow[t]{2}{*}{$\%$} \\
\hline & & $\mathrm{N}$ & $\%$ & & $\%$ & & \\
\hline 1 & $\begin{array}{l}\text { Menggunakan } \\
\text { Alat Pelindung } \\
\text { Diri pada saat } \\
\text { bekerja dan } \\
\text { meminum teh } \\
\text { kurkumin } \\
\text { kunyit setelah } \\
\text { bekerja }\end{array}$ & 99 & 86 & 13,9 & $\begin{array}{c}10 \\
0\end{array}$ & 115 & 100 \\
\hline 2 & $\begin{array}{l}\text { Pernah } \\
\text { diberikan alat } \\
\text { pelindung diri } \\
\text { atau } \\
\text { penyuluhan } \\
\text { mengolah } \\
\text { kunyit menjadi } \\
\text { minuman } \\
\text { untuk } \\
\text { mencegah } \\
\text { gangguan } \\
\text { kesehatan }\end{array}$ & 0 & 0 & 115 & $\begin{array}{c}10 \\
0\end{array}$ & 115 & 100 \\
\hline 3 & $\begin{array}{l}\text { Tahu dengan } \\
\text { menggunkan } \\
\text { Alat Pelindung } \\
\text { diri seperti } \\
\text { masker dan } \\
\text { meminum the } \\
\text { kunyit dapat } \\
\text { mencegah } \\
\text { gangguan } \\
\text { kesehatan }\end{array}$ & $\begin{array}{c}11 \\
3\end{array}$ & $\begin{array}{l}98 \\
, 2\end{array}$ & 2 & 1,8 & 115 & 100 \\
\hline
\end{tabular}


Dinamika Kesehatan Jurnal Kebidanan dan Keperawatan Vol 10 No. 2 Desember 2019 ( ISSN: 2086-3454 EISSN: 2549-4058)

url: http://ojs.dinamikakesehatan.unism.ac.id DOI : https://doi.org/10.33859/dksm.v10i2

Analisis Manfaat Teh Kurkumin Kunyit Dan Pemakaian K3 Pada Petani Wanita Untuk Pencegahan Kanker Multiple Myeloma Di Berastagi Kab. Karo Tahun 2019

Dari 115 (100\%) yang ditanyakan terdapat 99

responden $(86,4 \%)$ tidak menggunakan

masker, tetapi ada 16 responden(16.6\%) yang

menggunakan alat pelindung diri walaupun

hanya menggunakan handuk kecil dan

saputangan sebagai pengganti masker atau

meminum teh kurkumin kunyit untuk

mencegah mual dan muntah setelah

menyemprot tanaman meskipun tidak rutin.

Dari $\quad 16$ responden $(16.6 \%)$ yang

menggunakan alat pelindung diri walaupun

hanya menggunakan handuk kecil dan

saputangan sebagai pengganti masker atau

meminum teh kurkumin kunyit untuk

mencegah mual dan muntah setelah

menyemprot tanaman meskipun tidak rutin,

hal tersebut mereka lakukan untuk melindungi

diri dari paparan pestisida. Dari 115 (100\%)

tidak pernah diberikan alat pelindung diri

ataupun minuman the kurkumin kunyit.

Mereka melalakukan hal tersebut karena

mereja merasa terganngu sewaktu mengadung

obat pestisida dan sewaktu menyemprot

tanaman dan merasa mual setelah menyemprot sehinggan mereka meminum teh kurkumin kunyit.

\section{Upaya pemeriksaan kesehatan}

Dari seluruh responden yang ditanyakan secara keseluruhan tidak pernah dilakukan pemeriksaan kesehatan umum apalagi deteksi dini untuk kanker multiple myeloma. Mereka memeriksa kesehatan hanya karena mereka merasa ada keluhan saja itupun hanya dengan meminum obat. Hendaknya upaya upaya yang bersifat pencegahan (preventif), dibandingkan pengobatan (kuratif). Adapaun tujuan dari upaya-upaya pencegahan ini adalah pada masa sebelum sakit yang bertujuan untuk mempertinggi nilai kesehatan (Health Prmotion), memberikan perlindungan khusu terhadap penyakit (Spesific Prmomotion). Sedangkan pada masa sakit bertujuan untuk mengenal dan pada tingkat awal serta pengobatan yang tepat dan segera (Early diagnosis dan promp Treatment). Pembatasan kecacatan dan berusaha menghilangkan gangguan kemmapuan bekerja yang diakibatkan sesuatu penyakit 
Dinamika Kesehatan Jurnal Kebidanan dan Keperawatan Vol 10 No. 2 Desember 2019 ( ISSN: 2086-3454 EISSN: 2549-4058)

url: http://ojs.dinamikakesehatan.unism.ac.id DOI : https://doi.org/10.33859/dksm.v10i2

Analisis Manfaat Teh Kurkumin Kunyit Dan Pemakaian K3 Pada Petani Wanita Untuk Pencegahan Kanker Multiple Myeloma Di Berastagi Kab. Karo Tahun 2019

(Disability Limitation), dan Rehabilitasi paling banyak digunakan sebagai obat

(Rehabilitation). (Entjang, 1991).

\section{Persentase Organ Tumbuhan Berkhasiat Obat}

Grafik 1. Persentase Organ Tumbuhan

Berkhasiat Obat

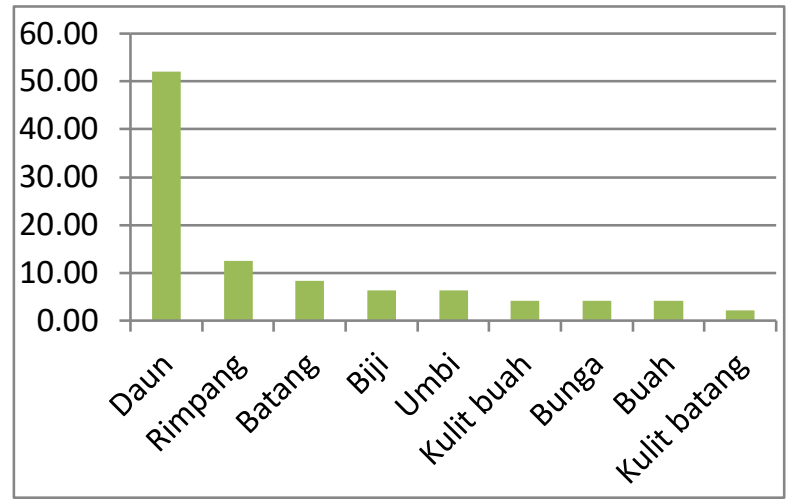

Dari Grafik diatas dapat dilihat bahwa

bagian organ tanaman yang sering dimanfaatkan sebagai obat tradisional adalah bagian daun dengan persentase $52,08 \%$. Daun paling tinggi intensitas penggunaannya karena mudah diperoleh daripada bagian organ tumbuhan lainnya. Daun merupakan organ tumbuhan yang pertumbuhannya terus menerus sehingga selalu tersedia pada tumbuhan. Dilihat dari segi konservasi, pengambilan daun sebagai tumbuhan obat tidak mengganggu dalam pelestarian tumbuhan obat tersebut.

Menurut Handayani (2003), daun merupakan bagian (organ) tumbuhan yang tradisional karena daun bertekstur lunak karena mempunyai kandungan air yang tinggi (70-80\%), selain itu, daun merupakan tempat akumulasi fotosintat yang diduga mengandung unsur-unsur (Zat organik) yang memiliki sifat menyembuhkan penyakit. Zat yang banyak terdapat pada daun adalah minyak atsiri, fenol, senyawa kalium dan klorofil. Keuntungan lain dari daun adalah memiliki serat yang lunak sehingga mudah untuk mengektrak zat-zat yang akan digunakan sebagai obat.

Bagian organ tumbuhan yang banyak digunakan adalah rimpang $12,50 \%$. Biasanya dari golongan famili Zingiberaceae diantaranya Lengkuas, Kunyit, Temulawak, Kencur, Jahe dan Lempuyang. Penggunaan rimpang oleh Suku simalungun telah banyak digunakan. Salah satunya adalah Jahe (Zingiber officinale) yang mengandung zat zingiberin yang mampu berperan sebagai antimikroba. 


\section{Simpulan}

Adapun kesimpulan yang diperoleh adalah

sebagai berikut:

1. Ekstraksi kurkumin merupakan cara yang sederhana dalam pengambilan kurkumin pada kunyit untuk mencegah permasalah kesehatan pada petani.

2. Memberikan pelatihan secara intensif kepada petani tentang pentingnya penggunaan K3 (Kesehatan dan Keselamatan Kerja) dalam kegiatan usahatani karena mampu melindungi petani dari bahaya kecelakaan kerja, menimbulkan rasa aman dan nyaman sehingga dapat menunjang peningkatan produktifitas kerja dan mampu mencapai tujuan yang telah ditetapkan.

\section{Saran}

1. Diharapkan pemerintahan Kabupaten Karo dapat memberikan penyuluhan secara berkesinambungan mengenai penggunaan pestisida yang aman dan tepat.

2. Meningkatkan kesadaran petani untuk melakukan perlindungan diri dari bahaya kimia melalui penggunaan alat pelindung diri dan kepatuhan terhadap prosedur penggunaan pestisida.

3. Dilakukannya pemeriksaan kesehatan khususnya enzim cholinesterase untuk mencegah keracunan pestisida dan meningkatkan kesehatan petani.

\section{DAFTAR PUSTAKA}

Fachry,A.R., Fenilla B,. Farhan M. Ekstraksi Senyawa Kurkumin dari Kunyit (Curcuma Longa Linn) Sebagai Zat Pewarna Kuning pada Proses Pembuatan Cat. Jurnal Teknik Kimia. No.3 Vol 19, 2014.

Harjanti,R.S., Pemungutan Kurkumin dari Kunyit (Curcuma domestica val.) dan Pemakaiannya Sebagai Indikator Analisis Volumetri. Jurnal Rekayasa Proses, Vol.2, No.2, 2008. Keenan, Kleinfelter, Wood, Pudjaatmaka,

A.H. Kimia Untuk Universitas. Erlangga. Jakarta, 1980. Mohammad, R., Ahmad, M., Daud,J.M,.Potensi Kurkumin Sebagai Penunjuk Ph Semula Jadi Untuk PembangunanSensor Optik pH, M.J.A.S II, 2007.

Nugroho N.A. Manfaat dan Prospek Pengembangan Kunyit. Trubus Agriwidya. Ungaran, 1998.

Rukmana,R. Kunyit. Kanisius. Yogyakarta, 1995

Fadhilah, Nurbaiti, Suryanto, and Nur Ulfah. 2013. "Faktor-Faktor Yang Mempengaruhi Kecelakaan Kerja Pada Proses Die Casting Di PT. X Cikarang Barat Kabupaten Bekasi Jawa Barat." Jurnal Kesmasindo 6(2):135-42. 
Gefen, David. 2002. "Customer Loyalty in ECommerce." Journal of the Association for Information Systems 3(May):27-51.

Geller, E. Scott. 2001. The Pschology of Safety Handbook. New York: Lewis Publisher.

Hasyim, Hasman. 2006. "Analisis Hubungan Karakteristik Petani Kopi Terhadap Pendapatan (Studi Kasus: Desa Dolok Saribu Kecamatan Paguran Kabupaten Tapanuli Utara)." Jurnal Komunikasi Penelitian 18(1):22-27.

Hayati, Ridha., Kasman, and Jannah Raudatul. $2018 . \quad$ "FaktorFaktor Yang Berhubungan Dengan Penggunaan Alat Pelindung Diri Pada Petani Penggguna Pestisida." Jurnal Kesehatan Masyarakat 8(1):11-17. 